\title{
Herpes Simplex Virus Type 1 Ribonucleotide Reductase Null Mutants Induce Lesions in Guinea Pigs
}

\author{
Steven R. Turk, ${ }^{*}$ Natalie A. Kik, ${ }^{*}$ Gary M. Birch, ${ }^{*}$ Daniel J. Chiego, JR., ${ }^{*}$ and C. Shipman, JR. ${ }^{*}+, 1$ \\ Departments of *Biologic and Materials Sciences, School of Dentistry, and +Microbiology and Immunology, \\ School of Medicine, The University of Michigan, Ann Arbor, Michigan 48109 \\ Received May 2, 1989; accepted July 11, 1989
}

\begin{abstract}
Two herpes simplex virus type 1 ribonucleotide reductase null mutants, hrR3 and ICP6A, produced cutaneous lesions in guinea pigs as severe as those of wild-type strains. The lesions induced by hrR3 resulted from in vivo replication of the mutant virus, suggesting that this virus-encoded enzyme is nonessential for virus replication in guinea pigs. () 1989 Academic Press, Inc.
\end{abstract}

The enzyme ribonucleoside diphosphate reductase (ribonucleotide reductase, EC 1.17.4.1) plays an essential role in the de novo synthesis of mammalian DNA, catalyzing the reduction of ribonucleoside diphosphates to 2'-deoxyribonucleoside diphosphates $(1,2)$. Herpes simplex virus type 1 (HSV-1) encodes its own unique ribonucleotide reductase which catalyzes the same reaction but which differs biochemically from its mammalian counterpart (3-6). In marked contrast to the mammalian enzyme which is highly regulated by nucleoside triphosphates, the viral enzyme is relatively free of allosteric control by dATP and dTTP $(3,4)$.

The utilization of the HSV-1 ribonucleotide reductase as a target for the design of antiviral drugs has attracted a great deal of interest recently $(7-9)$. For example, we and others have shown that 2 -acetylpyridine thiosemicarbazone and many of its congeners are inhibitors of the viral reductase (10-13) and show significant antiviral activity both in vitro and in vivo $(9,14$, 15). The usefulness of this enzyme as a target for the design of human antivirals has not been fully ascertained, however. The viral reductase with its lack of allosteric regulation undoubtedly enhances virus replication by increasing the deoxynucleotide pools utilized for viral DNA synthesis. Nutter and Cheng (1) have pointed out, however, that cellular DNA can be broken down within infected cells by virus-induced deoxyribonucleases as an alternate means of maintaining deoxynucleotide pools. Recent findings by Goldstein and Weller $(16,17)$ utilizing viral ribonucleotide reductase mutants indeed have substantiated the theory that the $\mathrm{HSV}-1$ enzyme is nonessential for the in vitro replication of this virus. In the present study we have examined these reductase mutants in a cutaneous herpes guinea pig model to investigate whether the viral reductase plays an essential function in virus replication in vivo.

Female standard Hartley and hairless [Crl:IAF $(\mathrm{HA}) \mathrm{BR}$ ] guinea pigs were obtained from Charles River

\footnotetext{
To whom requests for reprints should be addressed.
}

Laboratories (Wilmington, MA). Protocols using standard guinea pigs have been described in detail elsewhere (15). Procedures used with hairless guinea pigs were identical except for the exclusion of steps used to remove the animals' hair. In brief, animals were anesthetized, inoculated intradermally with virus at a titer of $3 \times 10^{6} \mathrm{PFU} / \mathrm{ml}$, and then observed daily for the production of lesions.

In our initial test of in vivo activity, separate areas on the backs of hairless guinea pigs were inoculated with the S-148 strain of HSV-1 commonly used in our animal model (15), the KOS strain of HSV-1 (from which the ribonucleotide reductase mutants were derived), and the reductase mutants hrR3 (16) and ICP6 $\Delta$ (17). hrR3 is an insertion mutant in which the lac $Z$ gene from Escherichia coli has been inserted within the coding region of ICP6, one of the two subunits of the viral reductase. The mutant produces a fusion protein in vitro which expresses $\beta$-galactosidase activity but no ribonucleotide reductase activity. ICP6 $\Delta$ is a deletion mutant in which $90 \%$ of the ICP 6 coding region has been excised. Again, no viral reductase activity is detectable in vitro following infection with this mutant. Lesions developing at the inoculation sites were scored daily for 10 days using the scoring system of Alenius and Öberg (18) and a statistical program was utilized to analyze the data using techniques of profile analysis, paired $t$ tests, and analysis of variance. Figure 1 illustrates that all four viruses induced vesicle formation in this model. A comparison of the individual curves revealed that the null mutants, in fact, were more expressive than either of the standard strains in this particular experiment $(P$ $\leqslant 0.002$ ). Given the lack of statistical significance observed in other experiments, however, we believe this observation of differences in lesion severity between virus strains to be coincidental. Both mutants also were capable of inducing lesions in the standard guinea pig (data not shown).

To substantiate that the formation of lesions by hrR3 was a result of virus replication, three different methods were employed: (i) In the first, an aliquot of hrR3 


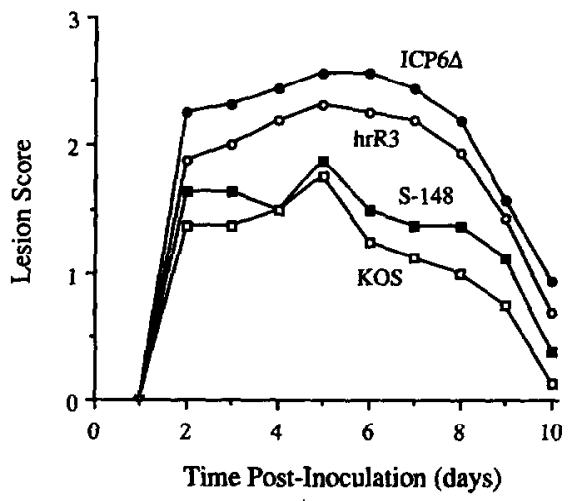

FIG. 1. Lesion formation in hairless guinea pigs by HSV-1 ribonucleotide reductase null mutants. Guinea pigs were inoculated intradermally with virus on Day 0 and the resultant lesions scored daily.

was heated at $95^{\circ}$ for 25 min while another aliquot was kept on ice. Each of the samples then was used to inoculate a standard guinea pig. Lesions developed on only the section receiving unattenuated virus, indicating that lesion formation was not merely a nonspecific immune response to the inoculation procedure or to foreign protein. (ii) In the second method, a standard guinea pig was inoculated with $\mathrm{hrR} 3$ and sacrificed 3 days postinfection. Areas of virus-inoculated skin were excised and homogenized as detailed in Shipman et al. (15). Homogenates were assayed for plaque-forming ability on an established line of African green monkey kidney (BSC-1) cells essentially as described previously (19), except that following a 4-day incubation of the cell monolayers with virus $1.5 \mathrm{ml}$ of a HEPES-buffered saline solution (20) containing $0.3 \mathrm{mg} 5$-bromo-4-chloro3-indolyl- $\beta$-D-galactoside (X-gal; Sigma Chemical Co., St. Louis, $\mathrm{MO}$ ) and $0.00125 \%$ neutral red were added to each well of the six-well tissue culture plate. Plaques were visualized within 3 days and all plaques developed a characteristic blue color upon staining, resulting from conversion of the colorless chromogenic substrate X-gal to a colored product by the $\beta$-galactosidase fusion protein induced by hrR3. Monolayers infected with KOS stock virus produced plaques which remained colorless upon staining with $X$-gal. The possibility that hrR3 obtained from skin samples represented residual virus inoculum was considered highly unlikely due to the thermosensitive nature of HSV-1. Calculations based upon a reported half-life at $37^{\circ}$ of $1.5(21)$ to $3(22) \mathrm{hr}$ suggested that the original inoculum was fully inactivated within $24 \mathrm{hr}-2$ days before skin samples were harvested. (iii) In the third method used to substantiate that lesion formation by $\mathrm{hrR} 3$ was a result of virus replication, hairless guinea pigs were inoculated with either hrR3 or KOS and sacrificed 4 days postinfection. Areas of virus-inoculated skin were excised and processed using a modification of methods described by Ho and Mocarski (23). Tissue was fixed $15 \mathrm{~min}$ in $0.5 \%$ glutaraldehyde in phosphate-buffered saline $(1 \mathrm{mM} \mathrm{MgCl}, 137 \mathrm{mM} \mathrm{NaCl}, 4 \mathrm{mM} \mathrm{KCl}, 8 \mathrm{mM}$ $\mathrm{Na}_{2} \mathrm{HPO}_{4}, 1.5 \mathrm{mM} \mathrm{KH}_{2} \mathrm{PO}_{4}$ ), washed free of glutaraldehyde, embedded in O.C.T. embedding medium (Miles Scientific, Naperville, IL), and frozen with liquid nitrogen. Thin tissue sections $(10 \mu \mathrm{m})$ were cut, collected onto glass slides, and dried. Slides were incubated overnight in phosphate-buffered saline containing 2.4 $\mathrm{mM}$ X-gal, $12.5 \mathrm{mM} \mathrm{K} \mathrm{K}_{3} \mathrm{Fe}(\mathrm{CN})_{6}$, and $12.5 \mathrm{mM}$ $\mathrm{K}_{4} \mathrm{Fe}(\mathrm{CN})_{6}$ and then counterstained with Harris's hematoxylin solution (24). Figure 2 illustrates the staining pattern obtained from a skin section taken from an hrR3-infected animal. Against a violet background of nuclear staining by hematoxylin can be seen a turquoise viral lesion, indicative of the presence of $\beta$-galactosidase activity. This finding indicates that the genetically engineered hrR3 genome was transcribed and the fusion protein translated in vivo. The fact that the entire vesicle was stained blue rather than just individual cells initially infected suggests that the mutant had undergone at least one lytic cycle of replication. Skin sections containing lesions induced by the KOS strain of HSV-1 did not stain blue upon incubation with $X$-gal nor was any nonspecific blue staining observed. Taken together these three observations indicate that the reductase mutant hrR3 is fully capable of replicating and producing cytopathology in the guinea pig.

The demonstration of unimpaired in vivo activity by ribonucleotide reductase null mutants contrasts markedly with the recent findings of other investigators. Cameron et al. (25) have reported that the virulence of two temperature-sensitive reductase mutants was severely impaired in mice. Examination of ICP $6 \Delta$ and KOS in mice by Coen and co-workers (26) revealed that the mutant, but not the parent strain, was severely impaired in its ability to replicate in the eye and in trigeminal ganglia. The contrasting effects in different animal species also holds true in vitro. Coen and co-workers found that ICP6 $\Delta$ replicated less efficiently in vitro in cells of murine lineage than of simian origin. Similarly, we determined the virus titers of our mutant stock solutions using monolayer cultures of mouse embryo fibroblasts (3T3; provided by Dr. C. T. Hanks, The University of Michigan), guinea pig lung cells (JH4; obtained from the American Type Culture Collection, Rockville, MD), African green monkey kidney cells (BSC-1; American Type Culture Collection), and human foreskin fibroblasts (HFF) by methods previously reported (19). We found that ICP6 $\Delta$ and hrR3 both replicated $99 \%$ less efficiently in murine cells than in guinea pig, simian, or human cells (data not shown). Given the observations reported herein further investigation is warranted to ascertain whether the HSV-1 ribonucleotide reductase is essential for the in vivo replication of 


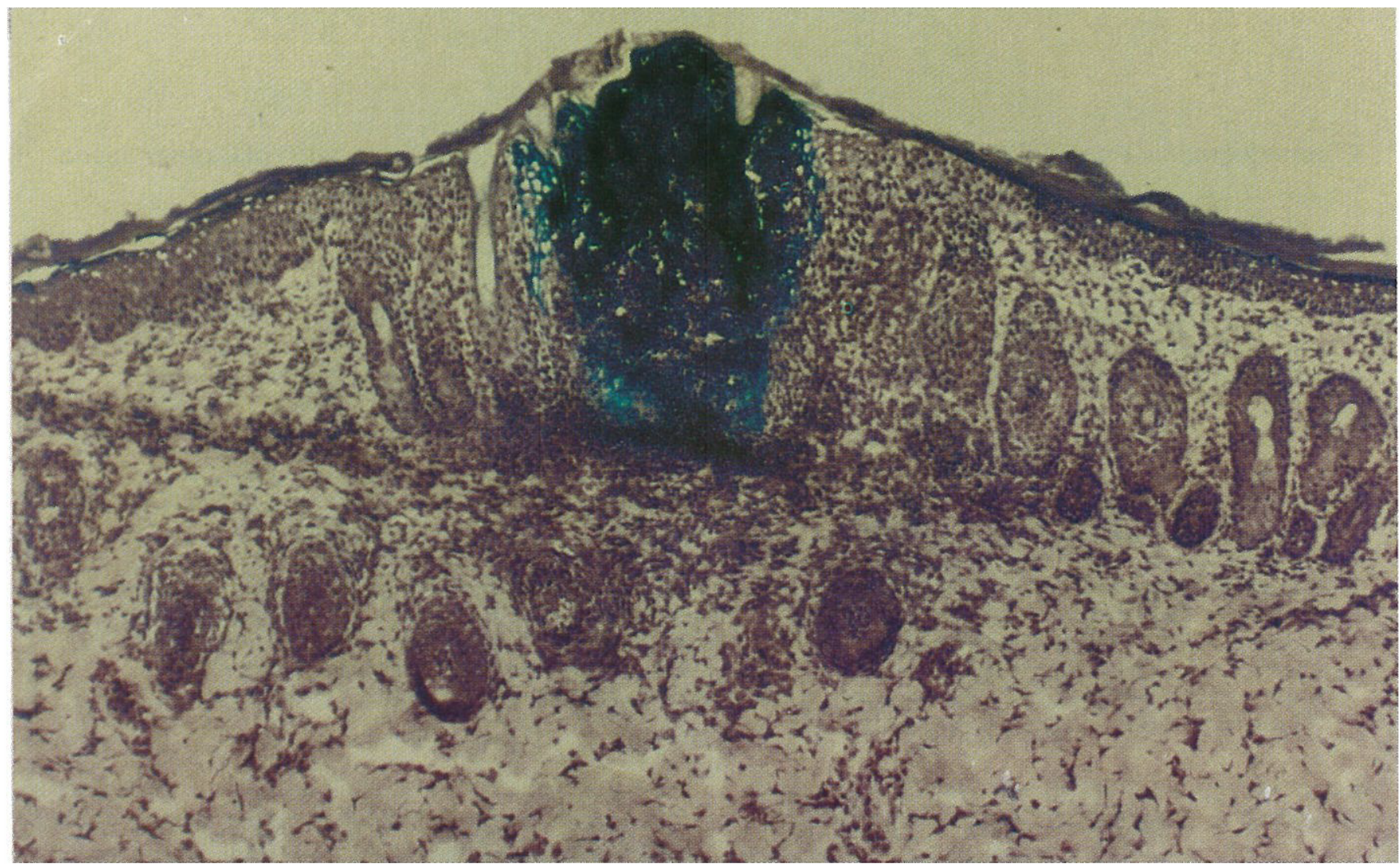

FIG. 2. Histochemical staining of an hrR3-induced lesion from guinea pig skin. Infected tissue was fixed and sectioned, stained with X-gal, and then counterstained with Harris's hematoxylin solution.

pathogenicity of this virus in other animal species and humans.

\section{ACKNOWLEDGMENTS}

We thank Drs. Sandra K. Weller and David J, Goldstein for providing the KOS, hrR3, and ICP $6 \Delta$ strains of HSV-1, Drs. Edward S. Mocarski and Donald $\mathrm{M}$. Coen for providing preprints of unpublished manuscripts, and John A. Baker and Dr. Jeffrey C. B. Stewart for their assistance in the histochemical staining and interpretation of tissue samples. This work was supported by Public Health Service Grant DE08510 from the National Institute of Dental Research.

\section{REFERENCES}

1. Nutter, L. M., and Cheng, Y.-C. Pharmacol. Ther. 26, 191-207 (1984).

2. Thelander, L., and ReIChard, P., Ann. Rev. Biochem. 48, 133158 (1979).

3. Averett, D. R., LubBers, C., Elion, G. B., and SpeCtor, T., J. Biol. Chem. 258, 9831-9838(1983).

4. COHEN, G. H., J. Virol. 9, 408-418(1972).

5. HusZAR, D., and BACCHETTI, S., J. Virol. 37, 580-588 (1981).

6. LANGELIER, Y., and BUTIIN, G., J. Gen. Virol. 57, 21-31 (1981).

7. Nakayama, K., Ruth, J. L., and Cheng, Y.-C., J. Virol. 43, 325327 (1982).

8. NUTtER, L. M., GRILL, S. P., and CHENG, Y.-C., Biochem. Pharmacol. 34, 777-780 (1985).

9. SPECTOR, T., Pharmacol.Ther. 31, 295-302 (1987).

10. SPector, T., AVerett, D. R., Nelson, D. J., Lambe, C. U., Morri-
Son, R. W., JR., St. Clair, M. H., and Furman, P. A., Proc. Natl. Acad. Sci. USA 82, 4254-4257 (1985).

11. SPECTOR, T., and JONES, T. E., J. Biol. Chem. 260, 8694-8697 (1985).

12. Turk, S. R., Shipman, C. JR., and DRACH, J. C., Biochem. PharmaCol. 35, 1539-1545 (1986).

13. Turk, S. R., Shipman, C., JH., and DraCh, J. C., J. Gen. Virol. 67, 1625-1632 (1986).

14. Shipman, C., IR., SMITH, S. H., Drach, J. C., and KI AYMAN, D. L., Antimicrob. Agents Chemother. 19, 682-685 (1981)

15. ShipMAN, C., JR., SMITH, S. H., DraCH, J. C., and KLAYMAN, D. L., Antiviral Res. 6, 197-222 (1986).

16. Golostein, D. J., and WELLER, S. K., J. Virol. 62, 196-205 (1988).

17. Goldstein, D. J., and Weller, S. K., Virology 166, 41-51 (1988).

18. Alenius, S., and Oberg, B., Arch. Virol. 58, 277-288(1978).

19. Turk, S. R., Shipman, C., JR., Nassiri, R., Genzlinger, G., KrawCZYK, S. H., TOWNSEND, L. B., and DRACH, J. C., Antimicrob. Agents Chemother. 31, 544-550 (1987).

20. Shipman, C., JR., Proc. Soc. Exp. Biol. Med. 130, 305-310 (1969).

21. SCOTT, T. F. M., MCLeOD, D. L., and TOKumaru, T., J. Immunol. 86, 1-12(1961).

22. Farnham, A. E., and Newton, A. A., Virology 7, 449-461 (1959). 23. Ho. D. Y., and MoCARSKI, E. S., Virology 167, 279-283 (1988).

24. PREECE, A., In "A Manual for Histologic Techniques" 3rd ed., pp. 227-228. Little, Brown, Boston, 1972.

25. Camerun, J. M., McDuugall, I., Marsden, H. S., Prestun, V. G., RYAN, D. M., and SUBAK-SHARPE, J. H., J. Gen. Virol. 69, 26072612 (1988).

26. Jacobson, J. G., Lieb, D. A., Goldstein, D. J., Bogard, C. L., ShafFer, P. A., Weller, S. K., AND COEN, D. M. Virology, in press. 